\title{
Gender Stereotypes in Fantasy Fairy Tales: Cinderella
}

\author{
Abir El Shaban \\ Language, Literacy and Technology \\ Department of Teaching and Learning \\ College of Education, Washington State University \\ Pullman, Washington, USA
}

\begin{abstract}
This paper explores gender stereotypes and culture depicted in three different versions of Cinderella children textbooks. The researcher has limited the study of fairy tales to Cinderella, the western version that she grew up reading it, and two other eastern versions: The Egyptian Cinderella and The Korean Cinderella. The characteristics of all versions represent different ethnics and cultural backgrounds. Findings that are based on discourse analysis show that the criteria of beauty and stereotype vary among all of the three versions of Cinderella children textbooks. That variation is based on the perspective of the culture represented in each one of the stories. Some valuable educational implications to limit the stereotypical gender misconceptions in children literature are presented to both parents and teachers.
\end{abstract}

Key words: children books; children literature; fairy tales; fantasy; gender; stereotypes

Cite as: El Shaban, A. (2017). Gender Stereotypes in Fantasy Fairy Tales: Cinderella. Arab World English Journal for Translation \& Literary Studies, 1(2).

DOI:http://dx.doi.org/10.24093/awejtls/vol1no2.10 